This item was submitted to Loughborough's Research Repository by the author.

Items in Figshare are protected by copyright, with all rights reserved, unless otherwise indicated.

\title{
Linguistic commonality between universalism and particularism: a reply to Ipperciel (2007)
}

PLEASE CITE THE PUBLISHED VERSION

http://dx.doi.org/10.1111/j.1469-8129.2008.00351.x

\section{PUBLISHER}

(c) The author / Journal compilation @ ASEN/Blackwell Publishing Ltd

\section{VERSION}

AM (Accepted Manuscript)

\section{PUBLISHER STATEMENT}

This work is made available according to the conditions of the Creative Commons Attribution-NonCommercialNoDerivatives 4.0 International (CC BY-NC-ND 4.0) licence. Full details of this licence are available at: https://creativecommons.org/licenses/by-nc-nd/4.0/

\section{LICENCE}

CC BY-NC-ND 4.0

\section{REPOSITORY RECORD}

Antonsich, Marco. 2019. "Linguistic Commonality Between Universalism and Particularism: A Reply to Ipperciel (2007)”. figshare. https://hdl.handle.net/2134/16121. 


\title{
Linguistic commonality between universalism and particularism:
}

\section{A reply to Ipperciel (2007)}

\author{
Marco Antonsich, \\ School of Geography, Earth and Environmental Sciences \\ University of Birmingham, \\ Edgbaston, Birmingham B15 2TT \\ United Kingdom \\ Tel. ++44 (0) 1214145542 \\ Fax ++44 (0) 1214145528 \\ Email:m.antonsich@bham.ac.uk
}

Universalism (of values) and particularism (of political communities) are two terms which scholars have struggled for long time to tame into a dialectical relationship (Bader 1997: 773). More often than not, however, these two dimensions, which historically have legitimated the existence of civic nation-states, have caused uneasiness among intellectuals. How is indeed possible to confine a political community when its source of legitimacy is rooted not in the specifics of an ethnos, but in the appeal to universal values? The question is particularly relevant today, i.e. in an epoch in which, under the pressure of financial, communication, and migration flows, the isomorphism between sovereignty, territory, and identity seems to have become untenable ( Soysal, 1994; Appadurai 1996; Habermas, 1998; 2001a). Going beyond this isomorphism, the postnational discourse affirms indeed the divorce of the state from the nation or, to use the terminology that Smith (1995: 11) refers to Hobsbawm, the 'de-politicization' of the nation. This means that the space that once saw the coincidence between the political (state) and the cultural (nation) has to be re-thought, from a unitary space to a plural and fragmented socio-spatial constellation - the "postnational constellation', as indeed Habermas (2001a) calls it. This postnational condition 
has fed (and it has been fed by) the re-conceptualization of the notion of citizenship. In her seminal work, Soysal (1994) has shown the increasing decoupling of rights and identity, as citizenship is increasingly decoupled from belonging to the national community. In Western Europe's multicultural societies, citizenship is no longer a cultural, but only a political dimension. In other words, it is no longer national belonging which constitutes the source of rights and duties, but human rights, which are legitimated at the transnational level. Thus, for instance, as Soysal (2002: 140) recalls when Pakistani immigrants in Britain demand the teaching of Islam in state schools, they appeal to the principle of human rights and, consequently, it is not surprising that they activate the European Court of Human Rights on this issue.

This postnational thesis can be discarded as merely 'unrealistic', as Schnapper (2002: 10), for instance, suggested from the pages of this journal. She argued that national identity and political allegiance have always gone together in the history of liberalism and therefore there is no reason to think that the future will be different. Yet, to discard a hypothesis by referring to evidence that comes from the past or by adducing, in a slightly essentialist tone, the emotional nature of human beings does not really help us to understand and answer the demand of inclusion associated with multicultural societies. If the statistical projection of the United Nations is true, by 2050, over $60 \%$ of the total populations of France, Germany, and Italy will be descendants of non-native born persons (United Nations 2000 quoted in Berezin 2003: 27). In this context, how is it possible to reproduce an ethno-cultural idea of the nation? Even if everybody is going to assimilate, it would be naïve to think that this process would not change the terms highlighted by Smith in his answer to the question 'when is a nation?' (Smith 2002). 
Ipperciel, among others, has not dismissed the postnational hypothesis as unrealistic, but, as a way to solve the original conundrum (how to reconcile universalism and particularism), he has taken seriously Habermas' theory - one of the most sophisticated intellectual efforts to reflect on the transformation of the nation-state in the age of globalization. Yet, despite Ipperciel's willingness to remain within the postnational terrain, his argument reveals some theoretical and pragmatic shortcomings when analyzed from this postnational perspective. In fact, theoretically, it seems to me that his reasoning ends up bringing the postnational back to a national dimension and, pragmatically, it leaves unanswered some questions about the actual feasibility of his hypothesis in today's multicultural world.

As it is well known, in his theory about 'constitutional patriotism', Habermas advocates a form of deliberative democracy which is not legitimated by the existence of an ethnos, 'a people' in ethno-cultural terms, but by a demos, a collectivity shaped by the same political culture. Put it differently, for Habermas cultural homogeneity is not a necessary condition for democracy, as engagement into the public sphere is what produce the collective opinion- and will-formation which secures legitimacy of and support to political institutions.

Ipperciel, however, notes that Habermas' reasoning leaves unanswered an important question: 'how are the democratic state's borders to be set?' (Ipperciel 2007: 400). Ipperciel's question does not focus on the lack of a common 'thick' cultural identity, which Schnapper and other communitarian authors (Miller 1995) have used to reject as unrealistic Habermas' model of constitutional patriotism. His question, instead, aims to give an answer to the seemingly irreconcilable relationship between universalism (the functioning of procedural democracy) and particularism (the necessity of drawing a geographical boundary around this democracy). Given the fact that 
Habermas is unable to answer this question (Ipperciel 2007: 400), Ipperciel, following 'a Habermasian logic beyond Habermas himself' (Ipperciel 2007: 398), essays to offer such an answer. The lack of a conspicuous reflection on this issue by postnational authors can be perhaps explained by the fact that these authors, following the postWestphalian argument ( Ruggie 1993; Anderson 1996; Albert et al. 2001), maintain that, in the present epoch, the modern distinction between inside-inclusion (domestic) and outside-exclusion (international) no longer holds, as boundaries have become increasingly porous, fuzzy, blurred, and in a permanent flux (Neumann 1998; Newman and Paasi 1998; Newman 2001; Zielonka 2002). Not surprisingly, Habermas, whose constitutional patriotism ultimately translates into a form of cosmopolitanism, has not given particular attention to the issue of boundaries. In practice, however, if we are not to believe, with Wendt (2003), that a world state is inevitable, then we should come to terms with the fact that, even in the age of globalization, societies remain separated into different political communities. This basic fact informs today also mainstream cosmopolitan theories, as Beck and Grande (2007), for instance, have recently argued against a cosmopolitanism tied to the 'cosmos' and have privileged instead a 'cosmopolitan realism', i.e. an ethical approach aimed at pursuing one's own interests in the respect of others' interests. Ipperciel's question, therefore, even though not a privileged one by postnational authors, is definitely relevant. Yet, his answer seems to me rather problematic. In his search for the rationale which can be used to define the boundaries of contemporary postnational democratic societies, Ipperciel points indeed to the importance of language: 'common language is a sine qua non of public discussion' (Ipperciel 2007: 400). Public discussion is, following Habermas, the essential criterion for developing a political culture on which constitutional patriotism is based, ergo commonality of language is they key principle for drawing the 
boundaries of the democratic state. Logically, the reasoning is consistent. Theoretically, however, it brings Habermas' postnational dimension back into a national one. As it is well known, language is one of the criteria traditionally used by students of nationalism to trace the boundaries of the nation (Gellner 1983; Smith 1995). Ipperciel (2007: 401) explicitly mentions that his use of the notion of language is not a Herderian one - language as a depositary of culture, tradition, history, etc. - but a functional one - language as a medium of communication. Yet, Ipperciel also admits that to separate the two dimensions is impossible, as language as a function 'does not in any way invalidate its cultural aspect as bearer of tradition' (Ipperciel 2007: 401) - a point that clearly emerges from Ipperciel's account of eighteenth century France. It is precisely because of this intrinsic symbolic character that Habermas has discarded any notion of commonality of language in his postnational model: "[...] a political culture in the seedbed of which constitutional principles are rooted by no means has to be based on all citizens sharing the same language [...]" (Habermas 1992: 7). Referring specifically to Europe as a would-be postnational society, Habermas has reiterated this point, by expressly rejecting the formation of a monolingual (English-speaking) public sphere, which would be constituted only by a business elite, and he has favored, instead, the persistence of national public spheres and the use of translation, which would guarantee a larger democratic participation (Habermas 2001b: 18-19). I am not therefore sure whether Ipperciel's reasoning can really consider itself 'to follow a Habermasian logic beyond Habermas himself’ (Ipperciel 2007: 398).

These last considerations bring me to the pragmatic shortcomings which I see in Ipperciel's thesis. As a way to test his hypothesis, Ipperciel briefly analyzes the cases of what, as he says, are the 'four multilingual nation-states among all the Western 
countries' - namely, Belgium, Spain, Switzerland, and Canada. ${ }^{1}$ Contrary to Miller's (2001) interpretation of sub-state nations as 'nested nationalities', Ipperciel affirms that 'multilingualism is not an attribute of the nation, but of the state' (Ipperciel 2007: 407) and all the four case-studies confirm, according to Ipperciel, that language is what sets each public sphere apart from another. In a linear, causal scheme this would read as follows: one language $=>$ one public sphere $=>$ one (civic) nation. Strangely enough, though, this scheme undermines the fact that, for instance, in Catalonia-, participation to the public sphere can also take place in Spanish, rather than in Catalan or, in the case of the Italian region of Valle d'Aosta-Vallée d'Aoste, the process of opinion- and will-formation takes place both in Italian and in French. Moreover, if we have to espouse Ipperciel's thesis, it would be difficult to explain why, for instance, Scotland, despite being overwhelmingly English-speaking, is today again on its way to ask for independence. Similarly, it would be simply impossible to think of any future European political integration, given the lack of a medium of communication which is mastered by all its citizens. More importantly, however, I think that the limits of Ipperciel's thesis emerge in relation not to multinational states - as he argues -, but to multicultural societies, which I think generate today the most urgent questions about inclusion/exclusion. While multinational states are formed by national communities which generally claim a specific portion of the state's territory as their homeland, multicultural societies are formed by immigrant communities whose homeland is somewhere else, outside the boundary of the state where they live. This often means that these immigrant communities are scattered all over the territory of the state. Cul-

\footnotetext{
${ }^{1}$ As a geographer, I guess I should point out that the Western democratic countries where 'more than one official or public language is recognised within the state' (Ipperciel 2007: 407) are actually much more than four. If we focus only on Europe, these countries are Italy (Italian, French, German, and Ladin), Portugal (Portuguese and Mirandese), Finland (Finnish and Swedish), Ireland (English and Gaelic), Austria (German, Croatian, Hungarian and Slovene), and Bosnia and Herzegovina (Bosnian, Croatian, and Serbian).
} 
tural-linguistic boundaries run confusingly inside the territory of the state and make impracticable any attempt to use language as a criterion (albeit only 'political', as stressed by Ipperciel) to draw the geographic boundary of the political community. How is it indeed possible to draw a boundary around something which is spatially fragmented? Multicultural societies defy the idea, invented by late eighteen century France, of a cultural-linguistic boundary which must run along the boundary of the state. The boundary of the nation and the boundary of the state today no longer match - if they have ever matched in the past either.

In an epoch in which societies become even more multilingual, as several languages coexist in the same place and at the same time, a common language as a medium of inter-individual communication is needed, but to use it as a criterion for binding social spaces can generate unreflexive undemocratic effects. In fact, this choice risks reinforcing the condition of exclusion of some of those immigrants who do not (yet) master the language of the dominant culture in which they are immersed. Rather than creating an environment of inclusion, as in the original spirit of Habermas' postnational model, the choice of a common language as a criterion for drawing the boundaries of the democratic space would reproduce and reify social marginalization and exclusion, at least for some first generation immigrants. I am not criticizing the necessity to have a common medium of communication. I am only questioning both the feasibility and the democratic nature of language as the principle of inclusion/exclusion in multicultural societies.

To conclude, does this means that we have to live with the irreconcilability of universalism and particularism, as we lack a principle which can be used to set a geographic boundary around a democratic space? I think that this conundrum can be loosely solved by reading Habermas himself and other authors too. In the introduction 
to The Postnational Constellation, Max Pensky (2001) pointed out that in Habermas, universalism, as a moral and political principle, 'can only be plausibly realized through the very particular history, traditions, and forms of life that continue to characterize national cultures' (Pensky 2001: xii - see also Fine and Smith 2003: 471). Similarly, espousing Rawls’ liberal contractualist position, Andreas Føllesdal (2000) has argued that although societies are regulated by the sense of justice of individuals who comply with rules which emanate from just institutions and which apply to them, the origin of societies can only rely on a shared history. These comments suggest that it is always historical the dimension for which societies become bound. No single factor accounts for the process of boundary-making, as this is the product of an ensemble of different practices which accumulate in the course of history: different modes of production, different wars (which create spaces of inclusion/exclusion in a Schmittean sense), and different relations of affiliation, identification, agon, and estrangement, as in Isin's (2002) forms of being political. To reduce ad unum (i.e. language) the principle which can justify the bounding of political communities would fail to take into account the living complexity of societies or, in Calhoun's words, 'the richer ways of constituting life together' (Calhoun 2002: 151). 


\section{References}

Albert, Mathias et al. (eds.). 2001. Identities, Borders, Orders: Rethinking International Relations Theory. Minneapolis: University of Minnesota Press.

Anderson, James.1996. 'The shifting stage of politics: New medieval and postmodern territorialities?' Environment and Planning D: Society and Space 14: 133-153.

Appadurai, Arjun. 1996. 'Sovereignty without Territoriality: Notes for a Postnational Geography,' in Patricia Yaeger (ed.), The Geography of Identity. Ann Arbor: The University of Michigan Press.

Bader, Veit. 1997. 'The cultural conditions of transnational citizenship: On the interpenetration of political and ethnic cultures', Political Theory 25: 771-813.

Beck, Ulrich and Grande, Edgar. 2007. 'Cosmopolitanism. Europe's way out of crisis', European Journal of Social Theory 10(1): 67-85.

Berezin, Mabel. 2003. 'Introduction: Territory, Emotion, and Identity: Spatial Recalibration in a New Europe', in Mabel Berezin and Martin Schain (eds.), Europe without Borders : Remapping Territory, Citizenship, and Identity in a Transnational Age. Baltimore: Johns Hopkins University Press.

Calhoun, Craig. 2002. 'Imagining solidarity: Cosmopolitanism, constitutional patriotism, and the public sphere', Public Culture 14(1): 147-171.

Fine, Robert and Smith, Will. 2003. 'Jurgen Habermas's Theory of Cosmopolitanism', Constellations 10(4): 469-487.

Føllesdal, Andreas. 2000. 'The future soul of Europe: Nationalism or just patriotism? A critique of David Miller's defence of nationality', Journal of Peace Research, 37(4):503-518.

Gellner, Ernest. 1983. Nations and Nationalism. Oxford: Blackwell. 
Habermas, Jürgen. 1992. 'Citizenship and national identity: Some reflections on the future of Europe', Praxis International 12(1): 1-19.

Habermas, Jürgen. 1998. The Inclusion of the Other. Studies in Political Theory. Cambridge: MIT Press.

Habermas, Jürgen. 2001a. The Postnational Constellation: Political essays, Cambridge: MIT Press.

Habermas, Jürgen. 2001b. 'Why Europe needs a constitution,' New Left Review 11: 526.

Ipperciel, Donald. 2007. 'Constitutional democracy and civic nationalism,' Nations and Nationalism 13(3): 395-416.

Isin, Engin F. 2002. 'Ways of being political', Distinktion 4: 7-28.

Miller, David. 1995. On Nationality. Oxford: Oxford University Press

Neumann, Iver B. 1998. 'European identity, EU expansion, and the integration/exclusion nexus', Alternatives 23(3): 397-416.

Newman, David. 2001. 'Boundaries, Borders, and Barriers: Changing Geographic Perspectives on Territorial Lines', in Mathias Albert et al. (eds.), Identities, Borders, Orders. Rethinking International Relations Theory. Minnepaolis: University of Minnesota Press.

Newman, David and Paasi, Anssi. 1998. 'Fences and neighbours in the postmodern world: boundary narratives in political geography', Progress in Human Geography, 22(2): 186-207.

Pensky, Max. 2001. 'Editor's Introduction', in Jürgen Habermas (ed.) The Postnational Constellation. Cambridge: MIT Press.

Ruggie, John Gerard 1993. 'Territoriality and Beyond: Problematizing Modernity in International Relations', International Organization 47(1): 139-174. 
Schnapper, Dominique. 2002. 'Citizenship and national identity in Europe', Nations and Nationalism 8(1): 1-14.

Smith, Anthony D. 1995. Nations and Nationalism in a Global Era. Cambridge: Polity Press.

Smith, Anthony D. 2002. 'When is a nation?' Geopolitics 7(2): 5-32.

Soysal, Yasemin Nuhoğlu. 1994. Limits of Citizenship: Migrants and Postnational Membership in Europe. Chicago: University of Chicago Press.

Soysal, Yasemin Nuhoğlu. 2002. 'Citizenship and Identity: Living Diasporas in Postwar Europe?', in Ulf Hedetoft and Mette Hjort (eds.), The Postnational Self. Belonging and Identity. Minneapolis: University of Minnesota Press.

Wendt, Alexander. 2003. 'Why a world state is inevitable', European Journal of International Relations 9(4): 491-542.

Zielonka, Jan. 2002. Europe Unbound: Enlarging and Reshaping the Boundaries of the European Union. London: Routledge. 